\title{
Predicting Consumer Intention to Use Mobile Payment Services: Empirical Evidence from Vietnam
}

\author{
The Ninh Nguyen ${ }^{1,2}$, Tuan Khanh Cao ${ }^{1}$, Phuong Linh Dang ${ }^{1} \&$ Hien Anh Nguyen ${ }^{1}$ \\ ${ }^{1}$ Department of Marketing Management, Vietnam University of Commerce, Hanoi, Vietnam \\ ${ }^{2}$ Faculty of Business and Law, Swinburne University of Technology, Melbourne, Australia \\ Correspondence: The Ninh Nguyen, Department of Marketing Management, Vietnam University of Commerce, \\ CauGiay District, Hanoi 100000, Vietnam. Tel: 84-37-687-682. E-mail: theninhnguyen.vcu@gmail.com
}

\author{
Received: December 28, 2015 Accepted: January 14, 2016 Online Published: January 28, 2016 \\ doi:10.5539/ijms.v8n1p117 URL: http://dx.doi.org/10.5539/ijms.v8n1p117
}

\begin{abstract}
Mobile payment has relative advantages compared to other payment methods, thus providing benefits for both consumers and the society. This study attempts to examine factors influencing consumer intention to use mobile payment services. Survey data are used to investigate the impact of consumers' perceptions of mobile payment services and social influence on use intention. Empirical evidence from 489 Vietnamese consumers confirms a significant relationship between the factors and behavioral intention, and reveals that perceived trust is the strongest predictor of intention to use mobile payment services followed by perceived ease of use, perceived enjoyment, perceived behavioral control, perceived usefulness and subjective norm, respectively. The results contribute to the evolving literature, and suggest that mobile payment service providers should particularly focus on building up consumer trust, and making their services clear, understandable and easy to use. Future research directions for extending this study are also discussed.
\end{abstract}

Keywords: mobile payment, consumer intention, mobile service providers, Vietnam

\section{Introduction}

Mobile payment, enabled by the burst of Internet, wireless technology and mobile devices, has received significant interest from academic researchers. While Kemp (2013) emphasizes that mobile payment is at the center of mobile commere, Pousttchi \& Wiedemann (2007) argue that it also works in different scenarios such as payment to a merchant or service provider and payment between consumers. Hence they refer to mobile payment as "a type of payment transaction processing in the course of which-within an electronic procedure-thepayer (at least) uses mobile communication techniques in conjunction with mobile devices forinitiation, authorization, or completion of payment" (Pousttchi \& Wiedemann, 2007). Similarly, Dahlberg et al.(2008) define mobile payment as any payments for goods, services and bills with a mobile device (e.g. mobile phone, smart phones, PDA, tablets). As such, mobile payment can supplement or replace cash, check, credit and debit cards in consumer daily purchase, and it can also serve as a means of entry to electronic accounts and payments.

There is growing awareness that mobile payment supplies economic benefits to the society as it has significant lower costs than cash-based services and existing card payments (Arvidsson, 2014; Mallat, Rossi, \& Tuunainen, 2004). Furthermore, it can generate competitive advantage for enterprises via its ubiquity and convenience (Chen, 2008; Mallat, 2007). Hence promoting consumers' usage of mobile payment services is of utmost importance for both Governments and marketers. Given the significance of mobile payment and the fact that most of prior studies focus on the settings of Western and developed countries (Ondrus \& Pigneur, 2005; Schierz, Schilke, \& Wirtz, 2010), there is indeed a need for more research into consumer intention to use mobile payment services in the context of emerging markets, such as Vietnam. According to an annual report (Appota, 2015), there were over 22 millions smartphone users (i.e. 23.25 percent population penetration) and 19.7 million $3 \mathrm{G}$ users in Vietnam by the end of 2014. Mobile devices including tablets and smartphones are the major means which are used for Internet access in the country (Consumer Barometer, 2015). Motivated by these impressive figures, key mobile payment service providers such as 1 Pay, MoMo, Payoo, Vimo, Moca and VNPAY has made every effort to attract consumers and increase market share. These enterprises either support or partner up with merchants, retailers, telecommunication companies and banks in order to provide various payment scenarios including 
payments of digital contents (e.g. games, applications, music), money transfer, mobile phone recharge and payment of bills

Inspired by the abovementioned discussions, this present study seeks to investigate factors that predict Vietnamese consumer intention to use mobile payment services. This study's findings are expected to consolidate knowledge on factors determining consumers' behavior towards mobile payment services, and provide relevant information for mobile payment service providers to develop marketing strategies and tactics aimed to motivate consumers to adopt and use their services.

\section{Potential Determinants of Intention to Use Mobile Payment Services}

Many studies pertaining to consumer behavior towards mobile payment services have built on the Technology Acceptance Model (TAM) (Davis, 1989), postulating that consumers' intention to adopt technology is influenced by perceived usefulness and perceived ease of use. As the literature evolves, this model has been extended. Authors such as Venkatesh \& Davis (2000) and Hung et al. (2003) suggest that subjective social norm is a determinant of users' intention to use mobile services. Several years later, Nysveen et al. (2005b) combine the TAM and the Theory of Planned Behavior (TPB) (Ajzen, 1985, 1991) with non utilitarian motives to posit that that intention to use mobile services is explained by consumerperceptions of multi-attributes, i.e. expressiveness, enjoyment, usefulness, ease of use, social influence and behavioral control. In addition, some researchers highlight the roles of trust and security in predicting such behavioral intention (Dahlberg, Mallat, \& Öörni, 2003; Dewan \& Chen, 2005; Lu, Yang, Chau, \& Cao, 2011). Given the variety of factors examined, this present study particularly focuses on the following determinants.

\section{Perceived Usefulness}

Perceived usefulness denotes the degree to which consumers believe that using a system would help them to perform jobs or duties better (Davis, 1989). Linking this to the domain of mobile payment service, consumers develop favorable attitude and intention towards such payment method because it has relative advantage compared to other methods such as cash, and card payments (Arvidsson, 2014; Mallat, 2007; Rogers, 1976). Various studies based on the TAM confirm the positive relationship between perceived usefulness and intentions to use mobile payment services (Nysveen, Pedersen, \& Thorbjørnsen, 2005a; Shin, 2009; Venkatesh \& Davis, 2000).

\section{Perceived Ease of Use}

Davis (1989) suggests that, despite performance benefits (i.e. perceived usefulness), consumers may not adopt use mobile services which require a great deal of effort in using. Hence he posits that perceived ease of use, indicating the effort or difficulty consumers derived throughthe use a particular mobile service, exerts direct influence on intention to use mobile service. As such, if consumers perceive that mobile payment services are easy to use, they are likely to use such services. Empirical evidence has converged into the prominent role of perceived ease of use in determining consumers' intentions to use mobile payment services (Cheong \& Park, 2004; Kim, Mirusmonov, \& Lee, 2010; Nysveen et al., 2005b).

\section{Perceived Enjoyment}

While perceived usefulness and perceived ease of use indicate extrinsic motivations, perceived enjoyment mentions intrinsic motivation which refers to "doing something because it is inherently interesting or enjoyable" (Ryan \& Deci, 2000). Intrinsic motivation is a major factor influencing behavioral intention to use technologies in the integrated model developed by Venkatesh et al. (2002). This supports the earlier argument that consumers use technologies because of rewards associated with them (Igbaria, Parasuraman, \& Baroudi, 1996). Some studies reveal that perceived enjoyment is significantly related to intention to use mobile chat services (Nysveen et al., 2005a) and mobile payment services (Nysveen et al., 2005b).

\section{Perceived Trust}

Gefen et al. (2003) argue that trust enhances predictive power of the TAM. Perceived trust is defined as a belief that a particular technological solution is secure and trustworthy or not (Dahlberg et al., 2003). Generally, consumers' trust in actors such as service providers, banks and payment service positively affects their intentions to use mobile service and subsequent behaviors (Arvidsson, 2014; Linck, Pousttchi, \& Wiedemann, 2006). Several qualitative studies (Dahlberg et al., 2003; Mallat et al., 2004) find out that consumers are more willing to use mobile payment service provided by trustworthy providers. This point is echoed in quantitative research demonstrating that consumer intention is influenced by reliability of mobile payment service and trustworthiness of providers (Lu et al., 2011; Mallat, Rossi, Tuunainen, \& Öörni, 2008; Zhou, 2013). 


\section{Subjective Norm}

Subjective norm represents perceived social pressure to perform a particular behavior (Ajzen, 1985). General speaking, the more favorable subjective social norms associated with a behavior, the stronger intention to conduct the behavior should be (Ajzen, 1991). While Mallat et al. (2008) reveal that social pressure is positively related to intention to use mobile ticketing service, Yang et al. (2012) conclude that influence from friends, colleagues and othersis critical factor affecting mobile payment adoption. It is striking that normative pressure has a positive effect on intentions to use mobile services including chat, text message, contact and payment (Nysveen et al., 2005a, 2005b).

\section{Perceived Behavioral Control}

Perceived behavioral control (PBC) refers to a set of beliefs about the presence or absence of resources and opportunities that may facilitate or impede the behavior of interest, hence it reflects the ease or difficulty to perform an action (Ajzen \& Madden, 1986). According to the TPB, if consumers perceive that the resources and opportunities available to them, they are more likely to perform a behavior. Given that mobile payment service requires mobile devices, wireless network and skills, it is argued that $\mathrm{PBC}$ is a key determinant of behavioral intention. Empirically, Nysveen et al. (2005a, 2005b) present a noticeable finding that consumers' intention to use mobile payment service is significantly influenced by PBC.

\section{Method}

\subsection{Design of Survey Instrument}

A draft of the survey instrument was developed by the authors and pre-tested before the main study. The pre-test used focus group and cognitive interviews with sixteen potential consumers to identify and correct potential problems relatingto questionnaire's structure and layout, question wording and clarity of instructions. The final rigorous questionnaire comprised of three main sections. The first section contained 20 items measuring six potential determinants. The second section included measure items for intention to use mobile payment services. All these measurement items were adapted from existing validated scales and analyzed by five-point Likert-type scales anchored at 1 for "strongly disagree" and 5 for "strongly agree". The third section sought to collect personal information of respondents.

Table 1. Summary of measures

\begin{tabular}{lllll}
\hline Variables & Number of items & Mean & Cronbach's Alpha & References \\
\hline Perceived usefulness & 3 & 3.36 & 0.812 & Nysveen et al. (2005b) \\
Perceived ease of use & 4 & 3.02 & 0.785 & Nysveen et al. (2005b) \\
Perceived enjoyment & 4 & 3.04 & 0.912 & Nysveen et al. (2005b) \\
Perceived trust & 3 & 3.03 & 0.858 & Zhou (2013) \\
Subjective norm & 3 & 3.06 & 0.859 & Yang et al. (2012) \\
Perceived behavioral control & 3 & 3.63 & 0.752 & Nysveen et al. (2005b) \\
Intention to use service & 2 & 3.07 & 0.810 & Yang et al. (2012) \\
\hline
\end{tabular}

Table 1 summarizes measurement scales and corresponding references. Reliability analyses showed that the Cronbach's Alpha coefficients ranged from 0.752 to 0.912 , which indicated good internal consistency of reliability (Hair, Black, Babin, Anderson, \& Tatham, 2006).

\subsection{Sample and Data Collection}

Participants in this study were Vietnamese citizens who were interested in mobile payment services. This ensured that participants would provide meaningful responses about their perceptions and intentions to use the services. Also, in order to collect data from various types of consumers, structured interviews using the questionnaire were conducted among participants in different places in six districts of Hanoi, including shopping malls, supermarkets, electronic and appliance stores, and resident neighborhoods. Participants were briefly explained about the research purposes and informed consent statement. Their participation was on voluntary basis.

The duration of the data collection was six weeks and the final effective sample was 489 participants. Table 2 exhibits sample demographics. Fifty-two percent of the participants were female and forty-eight percent were male. The age analysis showed that most of the participants aged between 30 and 39, representing approximately fifty-five percent of the sample. The median household income was VND 10,000,001-15,000,000 per month. 
Also, the educational statistics indicated that around fifty percent of the sample obtained bachelor degree, and twenty percent had postgraduate degree.

Table 2. Sample demographics

\begin{tabular}{llll}
\hline Characteristics & & Frequency & Percentage \% \\
\hline Gender & Male & 235 & 48.1 \\
Age & Female & 254 & 51.9 \\
& $18-29$ & 90 & 18.4 \\
& $30-39$ & 269 & 55.0 \\
& $40-49$ & 62 & 12.7 \\
Education & $50-59$ & 54 & 11.0 \\
& Over 59 & 14 & 2.9 \\
& Below high school & 16 & 3.3 \\
& High school & 36 & 7.4 \\
Family income (VND) & College's degree $(<=3$ years) & 95 & 19.4 \\
& Bachelor degree & 244 & 49.9 \\
& Postgraduate degree & 98 & 20.0 \\
& Under 5,000,000 & 32 & 6.5 \\
& $5,000,000-10,000,000$ & 55 & 11.2 \\
Total & $10,000,001-15,000,000$ & 213 & 43.6 \\
\hline
\end{tabular}

\section{Results}

Bivariate correlations and multiple regression were performed to examine the effect of potential determinants on behavioral intention. Table 3 shows the inter-correlations between variables examined in this study. Accordingly, a significant positive relationship was found between use intention and the six determinants $(p<0.01)$.

Table 3. Correlation matrix between variables

\begin{tabular}{|c|c|c|c|c|c|c|}
\hline & 1. & 2. & 3. & 4. & 5. & 6. \\
\hline \multicolumn{7}{|l|}{ 1. Usefulness } \\
\hline 2. Ease of use & .546 & & & & & \\
\hline 3. Enjoyment & .402 & .392 & & & & \\
\hline 4. Subjective norm & .431 & .536 & - & & & \\
\hline 5. $\mathrm{PBC}$ & .436 & .289 & .213 & .172 & & \\
\hline 6. Trust & .608 & .468 & .316 & .406 & .383 & \\
\hline 7. Intention & .718 & .731 & .507 & .522 & .516 & .764 \\
\hline
\end{tabular}

Note. Table contained only significant correlation at the 0.01 level (2-tailed).

In order to examine the integral role of the determinants in predicting the extent of consumers' intention to use mobile payment services, all variables were entered into a multiple regression equation. Prior to interpreting the regression results, issues of multicollinearity and multivariate outliers were inspected. Possible problems of multicollinearity were not of concern as each predictor had a tolerance value of more than 0.5 (Tabachnick \& Fidell, 2001) and a variance inflation factor (VIF) less than three (Stevens, 2012). The maximum Mahalanobis distance (17.4) did not exceed the critical $\chi^{2}$ (22.5), indicating the multivariate outliers were eliminated.

Table 4 depicts the key results of the regression.In combination, the six predictors explained a significant $83.9 \%$ of the variation in use intention, $R^{2}=0.839, F(6,482)=418.835, p<0.01$. More specifically, usefulness $(B=$ $0.137, t(482)=4.814, p<0.01)$, ease of use $(B=0.317, t(482)=3.858, p<0.01)$, enjoyment $(B=0.181, t(482)=$ $8.260, p<0.01)$, subjective norm $(B=0.131, t(482)=4.955, p<0.01)$, $\mathrm{PBC}(B=0.209, t(482)=8.292, p<0.01)$ and trust $(B=0.371, t(482)=15.521, p<0.01)$ contributed significantly to the regression model. That is, consumers' intention to use mobile payment services were facilitated by their perceptions of trust, ease of use, behavioral control, enjoyment, subjective norm and usefulness relating to the service. Also, by examining the standardized regression coefficients, trust $(\beta=0.375)$ appeared to be the strongest predictor that contributed to the variance in use intention, followed by ease of use $(\beta=0.305)$ and enjoyment $(\beta=0.177)$ respectively. 
Table 4. Key results of regression analysis

\begin{tabular}{|c|c|c|c|c|c|c|c|c|c|}
\hline Model & $\mathrm{R}$ & R Square & Adju & quare & Std. & f the Estimate & Durbi & atson & \\
\hline 1 & $.916 \mathrm{a}$ & .839 & .837 & & .419 & & 1.764 & & \\
\hline Coefficients & & & & & & & & & \\
\hline Model & & Unstandardizec & Coefficients & Standi & dized & $\mathrm{t}$ & Sig. & Collinearit & tatistics \\
\hline & & B & Std. Error & Beta & & & & Tolerance & VIF \\
\hline (Constant) & & -1.182 & .105 & & & -11.222 & .000 & & \\
\hline Usefulness & & .137 & .029 & .127 & & 4.814 & .000 & .476 & 2.099 \\
\hline Ease of use & & .317 & .026 & .305 & & 12.060 & .000 & .523 & 1.912 \\
\hline Enjoyment & & .181 & .022 & .177 & & 8.260 & .000 & .725 & 1.380 \\
\hline Subjective norm & & .131 & .026 & .116 & & 4.955 & .000 & .612 & 1.633 \\
\hline PBC & & .209 & .025 & .171 & & 8.292 & .000 & .783 & 1.278 \\
\hline Trust & & .371 & .024 & .375 & & 15.521 & .000 & .572 & 1.747 \\
\hline
\end{tabular}

\section{Discussions and Conclusion}

This present study extends previous research in the domain of mobile payment behavior by integrating key components of the TAM and the TPB, and by including the impact of trust and enjoyment. In line with prior findings (Nysveen et al., 2005b; Schierz et al., 2010), this study reveals that personal beliefs, resources and social influences are significant predictors of intention to use mobile payment services.

Perceived trust noticeably exerts strongest influence on behavioral intention. As such, consumers are concerned about service providers' trustworthiness and payment system reliability. This echoed the arguments of authors such as Lu et al. (2011) and Dahlberg et al. (2003). Also, it is striking that, while ease of use is a strong determinant of use intention, the role of perceived usefulness in explaining intention to make payment via mobile devices is quite limited. These support the suggestion of Mallat et al. (2008) that, the tradition TAM may not be widely applicable to different settings. Furthermore, personal means and resources required for the use of mobile payment (e.g. mobile devices, bank account or cards, wireless network) significantly affect consumers' use intention. Interestingly, intrinsic motivation (enjoyment) and social pressure (subjective norm) are additional facilitators of intention to use mobile payment services.

The results have several important implications. Mobile service providers should particularly focus on building trust and making their payment services easy to use. In order to enhance trust, service providers should increase services' security and reliability, reduce transaction errors, and protect consumers' privacy. Enterprises in mobile payment industry should also make their services more compatible with target customers, and educate consumers by providing them with clear manual and instructions for use. Also, marketing communications should be used to deliver message that mobile payment services are pleasant and entertaining, thus increasing consumers' perceived enjoyment. In addition, service providers should pay close attention to consumers' resources and offer free use of services to improve their perceived control.

\section{Future Research}

More research would be beneficial to the comprehensive understanding of factors influencing consumers' intention to use mobile payment. Future research could investigate the antecedents of key variables such as trust and perceived ease of use in the context of emerging markets. Furthermore, given the gap between intention and actual behavior in many studies, there is a need for research into the relationship between intentions and actual use of mobile payment services. Also, investigation into the moderating effects of demographic factors, such as gender, income and age, on the use of mobile payment services would be valuable to the literature and mobile service providers.

\section{References}

Ajzen, I. (1985). From intentions to actions: A theory of planned behavior. German: Springer.

Ajzen, I. (1991). The theory of planned behavior. Organizational Behavior and Human Decision Processes, 50(2), 179-211. http://dx.doi.org/10.1016/0749-5978(91)90020-T 
Ajzen, I., \& Madden, T. J. (1986). Prediction of goal-directed behavior: Attitudes, intentions, and perceived behavioral control. Journal of Experimental Social Psychology, 22(5), 453-474. http://dx.doi.org/10.1016/0022-1031(86)90045-4

Appota. (2015). Mobile Outlook for 2015: Appota.

Arvidsson, N. (2014). Consumer attitudes on mobile payment services: results from a proof of concept test. International Journal of Bank Marketing, 32(2), 150-170. http://dx.doi.org/10.1108/IJBM-05-2013-0048

Chen, L. D. (2008). A model of consumer acceptance of mobile payment. International Journal of Mobile Communications, 6(1), 32-52. http://dx.doi.org/10.1504/IJMC.2008.015997

Cheong, J. H., \& Park, M. C. (2004). Mobile payment adoption in Korea: Switching from credit card. Paper presented at the ITS 15th Biennial Conference, Berlin, Germany, September.

Consumer Barometer. (2015). Country Report-Vietnam.

Dahlberg, T., Mallat, N., \& Öörni, A. (2003). Trust enhanced technology acceptance model-consumer acceptance of mobile payment solutions: Tentative evidence. Stockholm Mobility Roundtable, 22-23.

Dahlberg, T., Mallat, N., Ondrus, J., \& Zmijewska, A. (2008). Past, present and future of mobile payments research: A literature review. Electronic Commerce Research and Applications, 7(2), 165-181. http://dx.doi.org/10.1016/j.elerap.2007.02.001

Davis, F. D. (1989). Perceived usefulness, perceived ease of use, and user acceptance of information technology. MIS quarterly, 319-340. http://dx.doi.org/10.2307/249008

Dewan, S. G., \& Chen, L. D. (2005). Mobile Payment Adoption in the US: A Cross-industry, Cross-platform Solution. Journal of Information Privacy \& Security (Ivy League Publishing), 1(2), 4-28. http://dx.doi.org/10.1080/15536548.2005.10855765

Gefen, D., Karahanna, E., \& Straub, D. W. (2003). Trust and TAM in online shopping: an integrated model. MIS quarterly, 27(1), 51-90.

Hair, J. F., Black, W. C., Babin, B. J., Anderson, R. E., \& Tatham, R. L. (2006). Multivariate data analysis. Upper Saddle River, NJ: Pearson Prentice Hall.

Hung, S. Y., Ku, C. Y., \& Chang, C. M. (2003). Critical factors of WAP services adoption: an empirical study. $\begin{array}{llll}\text { Electronic Commerce Research and } & \text { 42-60. }\end{array}$ http://dx.doi.org/10.1016/S1567-4223(03)00008-5

Igbaria, M., Parasuraman, S., \& Baroudi, J. J. (1996). A motivational model of microcomputer usage. Journal of management information systems, 127-143. http://dx.doi.org/10.1080/07421222.1996.11518115

Kemp, R. (2013). Mobile payments: Current and emerging regulatory and contracting issues. Computer Law \& Security Review, 29(2), 175-179. http://dx.doi.org/10.1016/j.clsr.2013.01.009

Kim, C., Mirusmonov, M., \& Lee, I. (2010). An empirical examination of factors influencing the intention to use mobile payment. Computers in Human Behavior, 26(3), 310-322. http://dx.doi.org/10.1016/j.chb.2009.10.013

Linck, K., Pousttchi, K., \& Wiedemann, D. G. (2006). Security issues in mobile payment from the customer viewpoint. Paper presented at the the 14th European Conference on Information Systems (ECIS 2006), Göteborg, Schweden.

Lu, Y., Yang, S., Chau, P. Y. K., \& Cao, Y. (2011). Dynamics between the trust transfer process and intention to use mobile payment services: A cross-environment perspective. Information \& Management, 48(8), 393-403. http://dx.doi.org/10.1016/j.im.2011.09.006

Mallat, N. (2007). Exploring consumer adoption of mobile payments-A qualitative study. The Journal of Strategic Information Systems, 16(4), 413-432. http://dx.doi.org/10.1016/j.jsis.2007.08.001

Mallat, N., Rossi, M., \& Tuunainen, V. K. (2004). Mobile banking services. Communications of the ACM, 47(5), 42-46. http://dx.doi.org/10.1145/986213.986236

Mallat, N., Rossi, M., Tuunainen, V. K., \& Öörni, A. (2008). An empirical investigation of mobile ticketing service adoption in public transportation. Personal and Ubiquitous Computing, 12(1), 57-65. http://dx.doi.org/10.1007/s00779-006-0126-z 
Nysveen, H., Pedersen, P., \& Thorbjørnsen, H. (2005a). Explaining intention to use mobile chat services: moderating effects of gender. Journal of consumer Marketing, 22(5), 247-256.

Nysveen, H., Pedersen, P., \& Thorbjørnsen, H. (2005b). Intentions to use mobile services: Antecedents and cross-service comparisons. J. Acad. Mark. Sci., 33(3), 330-346.

Ondrus, J., \& Pigneur, Y. (2005). A disruption analysis in the mobile payment market. Paper presented at the System Sciences. HICSS'05. Proceedings of the 38th Annual Hawaii International Conference on. http://dx.doi.org/10.1109/hicss.2005.9

Pousttchi, K., \& Wiedemann, D. G. (2007). What Influences Consumers' Intention to Use Mobile Payments. Mobile Communications Working Group, University of Augsburg. Retrieved from: http://www. marshall. usc. edu/assets/025/7534. pdf.

Rogers, E. M. (1976). New product adoption and diffusion. Journal of consumer Research, 290-301. http://dx.doi.org/10.1086/208642

Ryan, R. M., \& Deci, E. L. (2000). Intrinsic and Extrinsic Motivations: Classic Definitions and New Directions. Contemporary Educational Psychology, 25(1), 54-67. http://dx.doi.org/10.1006/ceps.1999.1020

Schierz, P. G., Schilke, O., \& Wirtz, B. W. (2010). Understanding consumer acceptance of mobile payment services: An empirical analysis. Electronic Commerce Research and Applications, 9(3), 209-216. http://dx.doi.org/10.1016/j.elerap.2009.07.005

Shin, D. H. (2009). Towards an understanding of the consumer acceptance of mobile wallet. Computers in Human Behavior, 25(6), 1343-1354. http://dx.doi.org/10.1016/j.chb.2009.06.001

Stevens, J. P. (2012). Applied multivariate statistics for the social sciences. London, New York: Routledge.

Tabachnick, B. G., \& Fidell, L. S. (2001). Using multivariate statistics. MA: Allyn and Bacon.

Venkatesh, V., \& Davis, F. D. (2000). A theoretical extension of the technology acceptance model: Four

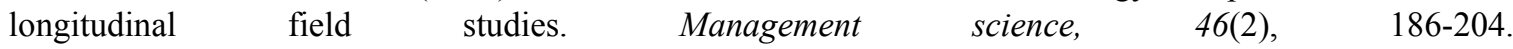
http://dx.doi.org/10.1287/mnsc.46.2.186.11926

Venkatesh, V., Speier, C., \& Morris, M. G. (2002). User acceptance enablers in individual decision making about technology: Toward an integrated model. Decision Sciences, 33(2), 297-316. http://dx.doi.org/10.1111/j.1540-5915.2002.tb01646.x

Yang, S., Lu, Y., Gupta, S., Cao, Y., \& Zhang, R. (2012). Mobile payment services adoption across time: An empirical study of the effects of behavioral beliefs, social influences, and personal traits. Computers in Human Behavior, 28(1), 129-142. http://dx.doi.org/10.1016/j.chb.2011.08.019

Zhou, T. (2013). An empirical examination of continuance intention of mobile payment services. Decision Support Systems, 54(2), 1085-1091. http://dx.doi.org/10.1016/j.dss.2012.10.034

\section{Appendix}

\section{Research Construct Items}

\section{Perceived usefulness}

Using mobile payment service makes me save time

Using mobile payment service improves my efficiency

Mobile payment service is useful to me

\section{Perceived ease of use}

Learning to use mobile payment service is easy to me

It easy to make mobile payment service do what I want to do

My interaction with mobile payment service is clear and understandable

It is easy to use mobile payment service

Perceived enjoyment

I find mobile payment service entertaining

I find mobile payment service pleasant 
I find mobile payment service exciting

I find mobile payment service fun

Perceived trust

The mobile payment service provider is trustworthy

The mobile payment service gives a reliable impression

The mobile payment service provider keeps customers' interest in mind

Subjective norms

People important to me think that I should use mobile payment service

It is expected that people like me use mobile payment service

People who influence my behavior expect me to use mobile payment service

\section{Perceived behavioral control}

I feel free to use the kind of mobile payment service I like to

Using mobile payment service is entirely within my control

I have necessary means and resources to use mobile payment service

Intention to use mobile payment service

Assuming I have access to mobile payment service, I intend to use it

Given that I have access to the mobile payment service, I predict that I would use it

\section{Copyrights}

Copyright for this article is retained by the author(s), with first publication rights granted to the journal.

This is an open-access article distributed under the terms and conditions of the Creative Commons Attribution license (http://creativecommons.org/licenses/by/3.0/). 